\title{
The Transmission of International Food Commodity Prices to China
}

\section{He Shuquan}

\author{
School of Economics, Shanghai University, China
}

\begin{abstract}
Food commodity prices stability is a great concern in developing countries. The food commodity prices spike during 2007-2008 has put many developing countries short of food supply. Food has been the key issue in China. In this paper, we aim to study the price stability of China's three main food commodities, examining the transmission of world prices of rice, maize and wheat to China during the recent food commodity prices spike and the factors influencing the transmission. The study contributes to the academic research by giving new insight to the transmission of world food price to developing countries. (1) To understand the world price transmission to China for these three food commodities, we conduct econometric analysis using monthly data. We perform the unit root test using Dickey-Fuller Test with GLS de-trending (DF-GSL) test for the data series and run the error-correction model (ECM) to estimate the price transmission. (2) The empirical results suggest that the price transmissions are weak, and china's prices of these three commodities are relative stable, with speeds of adjustment less than 5\%. (3) We go on to explore the factors that contribute to the week transmission. As an important factor to market price salability, China's production of rice, maize and wheat keeps an increasing trend during the last decades. And these are the results of reforming agriculture policies in China during the past years. The reforms are related to production, price, taxation and trade, etc. (4) With the empirical results and analysis from the policy perspective, we conclude that the food prices were relative stable during the world food price spike and this is attributed to the agricultural policy reform in China.
\end{abstract}

Keyword: Agricultural Policy, China, Food Commodity Prices

JEL Classification: C22, O24, Q11

(C) The Author, 2018. This article is published with open access at Sumy State University.

\section{Introduction}

Food commodity prices stability is a great concern in developing countries. It is also an interest to study the transmission of price changes in world food commodity market to domestic market in developing countries. Mundlak and Larson (1992) show that most of the variations in world prices are transmitted and that they constitute the dominant component in the variations of domestic prices. Baffes and Gardner (2003) examine the extend to which world price signals have been transmitted into domestic prices for eight developing countries and ten commodities, and the impact of the policy reform on the price transmission. Conforti (2004) provides more evidences on price transmission in a number of agricultural markets. Imai, Gaiha and Thapa (2008) study the case in China. They focus their study on the comparison between China and India from 1966 to 2005 , and explain why the transmissions in these two large developing countries differ.

The recent food commodity prices spike during 2007-2008 put many developing countries short of food supply. The so-called "world food crisis" that coalesced across the globe in 2007 and early 2008 when the price of rice, corn, wheat, soybeans, and food more generally skyrocketed illustrates many of the crises and contradictions of the contemporary global food economy. Riots due to food shortage happened in many developing countries across Asia, Africa, Middle East, the Americas and the Carribeans. ${ }^{1}$ Have recent increases in international cereal prices been transmitted to domestic economies? Dawe (2008) analyzes, for seven large Asian countries, the extent to which domestic prices have increased through 2003 to 2007 . He concludes that domestic commodity specific policies in several Asian countries have stabilized domestic prices relative to the change in world prices.

China is a developing country in which agriculture plays an important role. Though the share of agriculture in GDP has dropped to about $11-12 \%$ in recent years, nearly $30 \%$ of the total population still live on agriculture in China. In this paper, we study the stability of China's three food commodities: rice, Maize and wheat during 2006 to 2011. The next section gives a general picture of China's food commodity prices for rice, maize and

\footnotetext{
${ }^{1}$ Schneider, Mindi, 2008, "We are Hungry! A Summary Report of Food Riots, Government Responses, and States of Democracy in 2008”, December, Development Sociology, Cornell University.
} 
wheat. We focus on the transmission of world price variation to China with monthly data. The third section econometrically analyses the transmission of world prices to China. The fourth section is devoted to discussing the contributing factors to the price stability from the policy perspective. The last section concludes the paper.

\section{Recent Food Commodity Prices in China}

Food commodity prices fluctuated a lot during the past four decades, especially in the case of rice. Since 1970, over a period of about four decades, there were five food commodity prices spikes. As shown in Figure 1, these spikes appeared during 1974-76, 1980-82, 1988-90, 1995-97 and 2007-2008. And the current upward trend started from 2011. Each crisis lasted for about 2 years for a total of 10 years, or about $25 \%$ of the period. For the rest of the $75 \%$ of the time, world food prices could be said to be on decline trend or be depressed. This is the so called "25-75 characterization" of the global food commodity price (Sharma and Konandreas, 2008).

The recent food commodity prices spike during 2007-2008, which showed rising trends in 2006, brought turmoil in some developing countries. However, the prices for the three food commodities (rice, maize and wheat) kept relative stable in China. Figure 2 compares the Chinese prices of these three food commodities with those of the world. The world prices are drawn from International Monetary Fund (IMF) Commodity Price Database. ${ }^{1}$ And the Chinese prices are the national average wholesale prices provided by China Zhengzhou Grain Wholesale Market. ${ }^{2}$ China's prices are translated to US dollar with monthly average exchange rate provided by the People's Bank of China ${ }^{3}$. For world prices, wheat is US HRW price; rice is $5 \%$ broken, Thailand; Corn is US no. 2, yellow, f.o.b. US Gulf ports; soybeans (US) is CIF Rotterdam. For China's prices, wheat is white wheat (common, grade B), rice is indica paddy rice (grade A), and maize is yellow corn (grade 3). The prices used are monthly prices from January 2006 to June 2011.

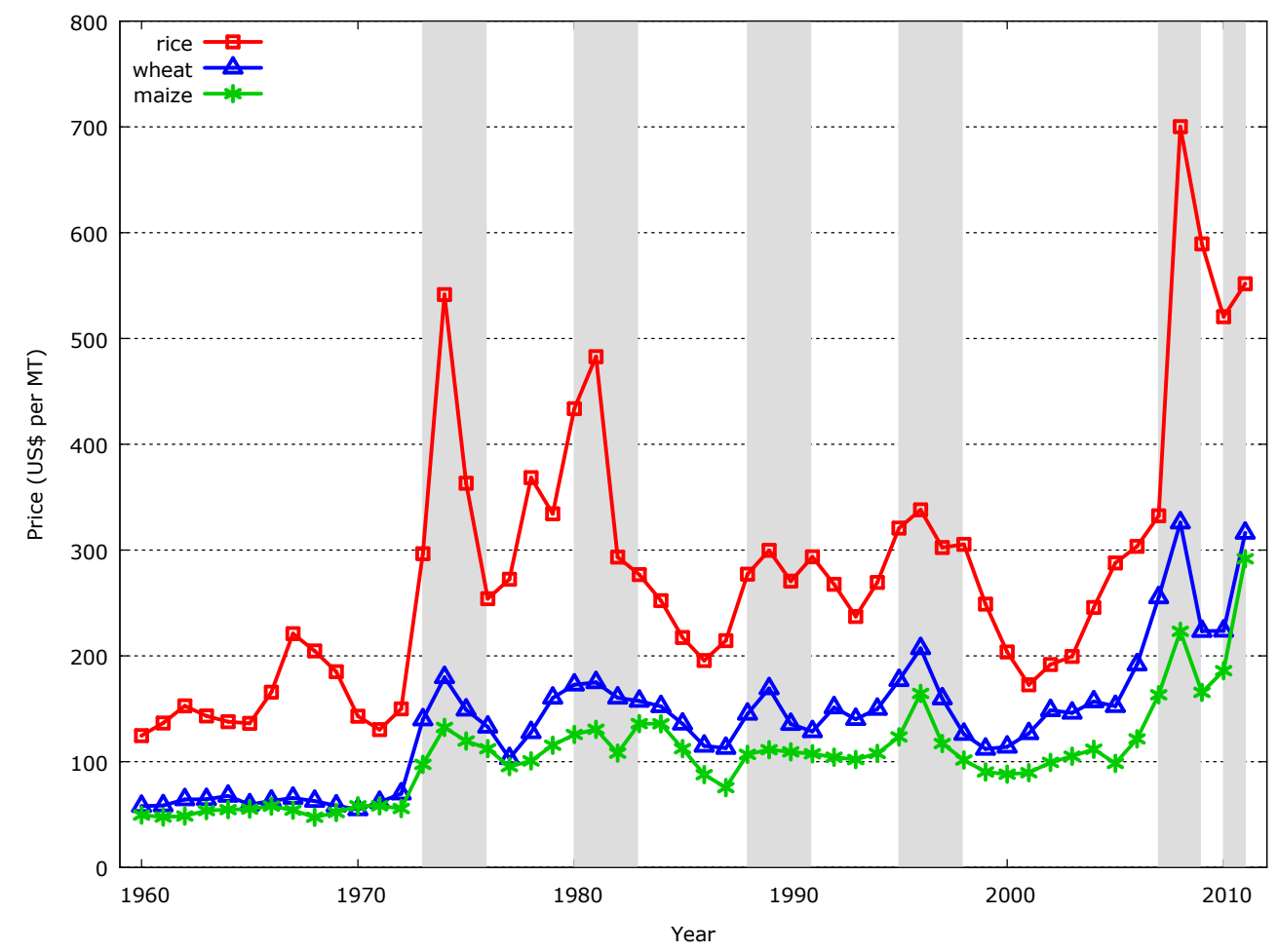

Figure 1 World Food Commodity Annual Prices, 1960-2011

Source: IMF Commodity Price Database.

\footnotetext{
${ }^{1} \mathrm{http}: / /$ www.imf.org/external/np/res/commod/index.aspx. October 25, 2011.

${ }^{2}$ http://price.cngrain.net/sinoprice/AvgPrice.htm. Accessed on October 25, 2011.

${ }^{3}$ http://www.pbc.gov.cn/publish/diaochatongjisi/133/index.html. Accessed on October 25, 2011.
} 


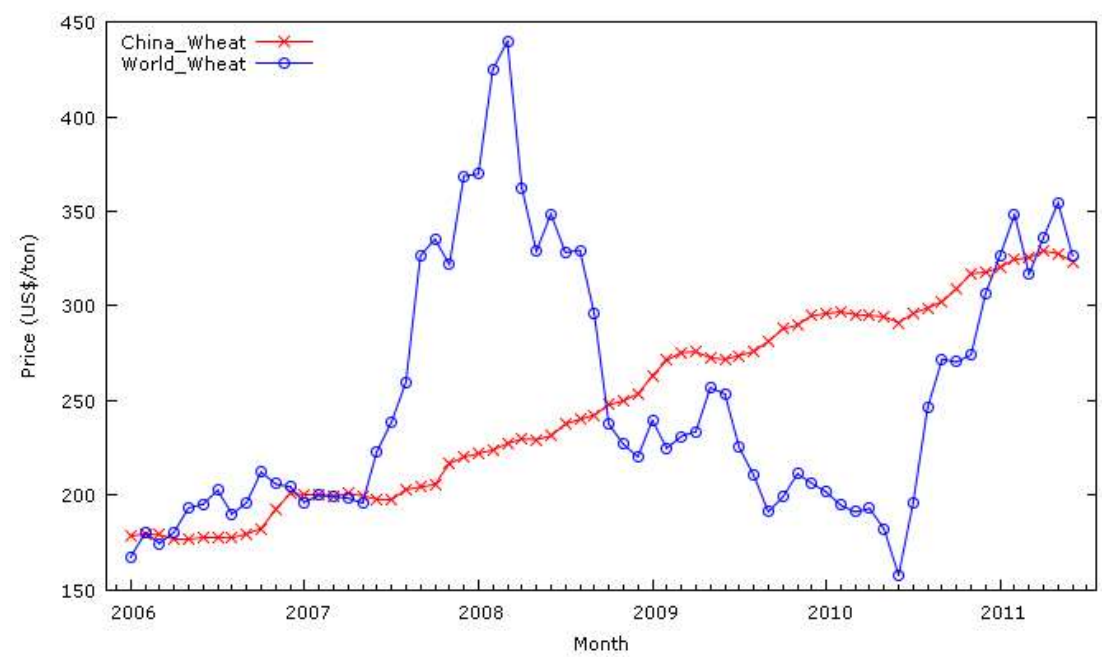

Wheat

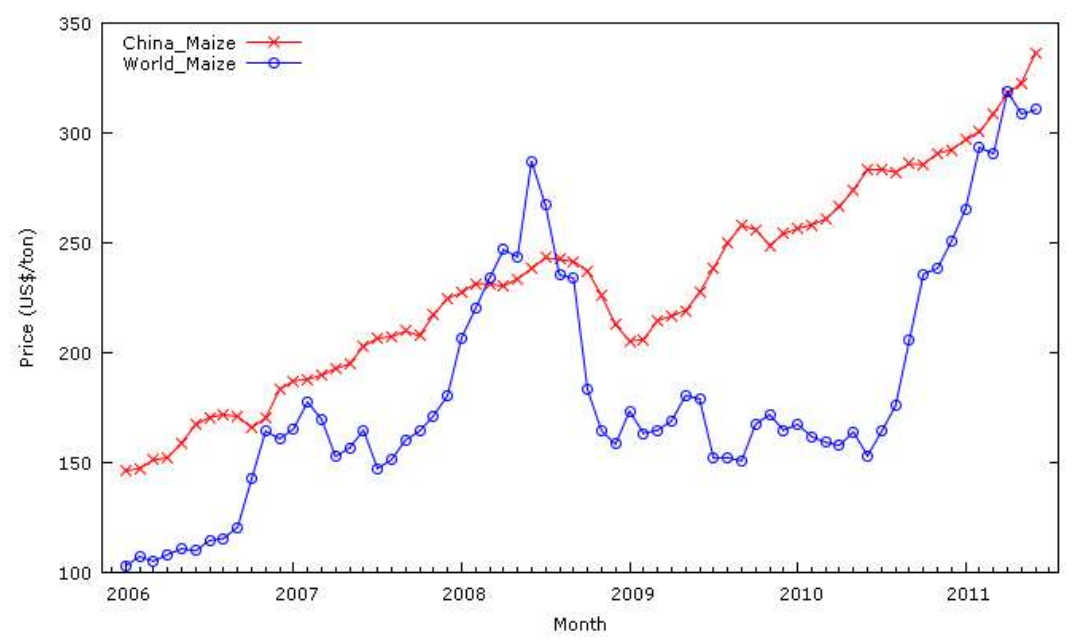

Maize

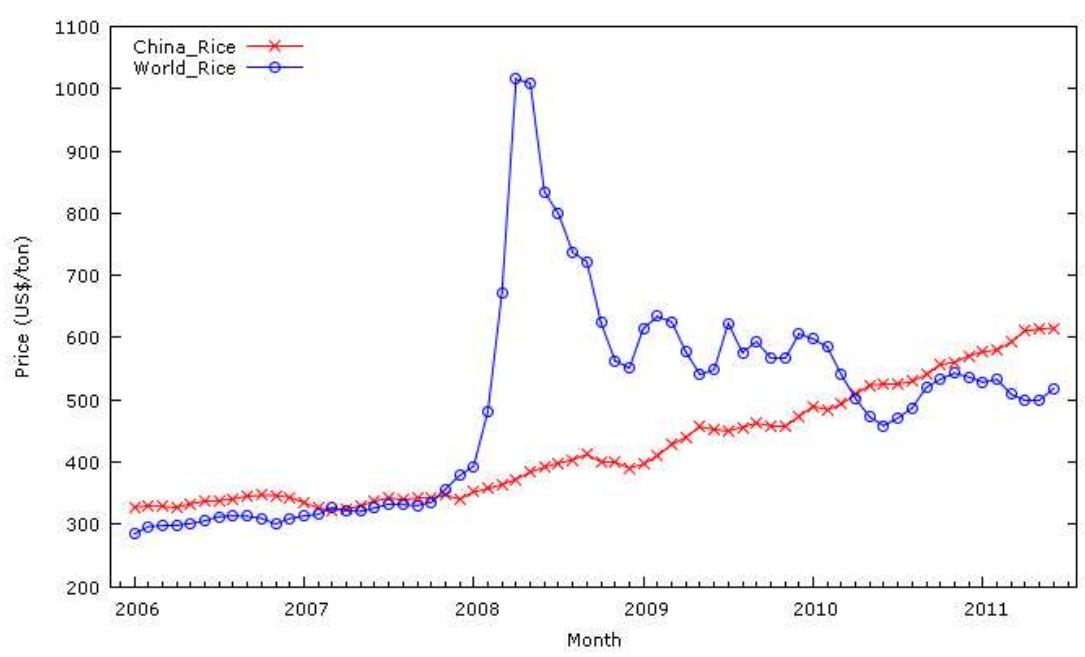

Rice

Figure 2. Food Commodity Monthly Prices of World and China, US\$ per ton, 2006-2008

Source: IMF Commodity Price Database and China Zhengzhou Grain Wholesale Market.

Figure 2 shows that Chinese price for the three food commodities kept their own trends when the world prices increase dramatically during 2007 to 2008. To confirm this point, we use the Error Correction Model (ECM) to test the transmission of world prices changes to the Chinese market. 


\section{Econometric Analysis}

2.1. Methodology. Earlier researchers use either bivariate correlation coefficient or static regression analysis to examine the relationship between commodity prices on different markets, say world market and domestic market. The former measurement doesn't capture dynamic relations among markets (Sharma, 2003). Equation (1) is the typical static regression form.

$$
P_{t}^{d}=\alpha+\beta P_{t}^{w}+\varepsilon_{t}
$$

where $P_{t}^{l}$ and $P_{t}^{v}$ are the domestic and world price of the commodity of interest, $\alpha$ and $\beta$ are parameters to be estimated while $\varepsilon_{t}$ denotes the error term. However, it presents fundamental shortcomings (Baffes and Gardner, 2003; Sharma, 2003): non-stationarity of the price series and high degrees of positive autocorrelation.

Dynamic models based on co-integrating relationships have now become the mainstream of the econometric time-series analysis. In applied works, the most common form of these dynamic models is the Error Correction Model (ECM), contributed largely by Granger and Engle (1987). It is closed related to Auto-regressive Distributed Lag (ADL) model. Its typical form is as expressed by equation (2), which appends one lag to (1).

$$
P_{t}^{d}=\alpha+\beta_{1} P_{t}^{w}+\beta_{2} P_{t-1}^{d}+\beta_{3} P_{t-1}^{w}+\varepsilon_{t}
$$

Following Hendry et al (1984), Baffes and Gardner (2003), Imai, Gaiha and Thapa (2008) restrict the slope parameters $\beta_{i}$ to sum up to unity. That is, suppose $\beta_{3}=1-\beta_{1}-\beta_{2} \equiv \beta_{\text {and }} 1-\beta_{2}=\gamma$. And the absolute value of $\beta_{3}$ is restricted to be less than unity. Thus equation (2) is rewritten as

$$
\left(P_{t}^{d}-P_{t-1}^{d}\right)=\alpha+\gamma\left(P_{t-1}^{w}-P_{t-1}^{d}\right)+\beta\left(P_{t}^{w}-P_{t-1}^{w}\right)+\varepsilon_{t}
$$

The main feature of equation (3) is the economic interpretation of its parameters: $\beta$ is the short-run effect coefficient. It indicates how much of a given price change in the price of the commodity in the world market will be transmitted to domestic market. $\gamma$ is referred to as the error-correction term or the speed of adjustment. It indicates how much of the past price difference between the two prices is eliminated in each period thereafter. It will be negative if the domestic piece is higher than the world price most of the times. The coefficient of the short-run effect can, in theory, take any value; the adjustment coefficient, however, is restricted between zero and two (Baffes and Ajwad, 1998; Baffes and Gardner, 2003).

Having established long-run proportionality, the next task is to answer this question: How long does it take for the domestic price to adjust to a given price change in world market? Let $n$ be the period by which $k$ percent of the cumulative adjustment has taken place. Baffes (1998), Baffes and Gardner (2003) show that $k$ is given by

$$
k=1-(1-\beta)(1-\gamma)^{n}
$$

Alternatively, solving for $n$ in (4) gives the number of periods required to achieve a certain level of cumulative adjustment $k$, i.e. $n=[\log (1-k)-\log (1-\beta)] / \log (1-\gamma)$. For values of $\beta$ and $\gamma$ close to unity, a small $n$ is required for the adjustment to be completed.

2.2. Econometric Results. We first perform the unit root test using Dickey-Fuller Test with GLS de-trending (DF-GSL) test for the series stationarity. Table 1 exhibits the results. Table 1 shows that the price series for China's maize and wheat, and rice for world are not stationary at level data. However, the price series are all stationary at their first differences. The price differentials between the world price and the Chinese price are stationary.

Table 1 Unit Root Tests with DF-GLS

\begin{tabular}{|l|c|l|l|l|l|l|}
\hline & \multicolumn{2}{|c|}{ China } & \multicolumn{2}{c|}{ World } & \multicolumn{2}{c|}{ Price Differentials } \\
\hline Level & & & & & & \\
\hline Maize & -1.52855 & & -4.1629 & $* * *$ & -4.46645 & $* * * *$ \\
\hline
\end{tabular}


Table 1 (cont.). Unit Root Tests with DF-GLS

\begin{tabular}{|l|c|c|c|c|c|c|}
\hline & \multicolumn{2}{|c|}{ China } & \multicolumn{2}{c|}{ World } & \multicolumn{2}{c|}{ Price Differentials } \\
\hline Rice & -3.34854 & $* *$ & -2.89056 & & -2.97761 & $*$ \\
\hline Wheat & -2.40748 & & -3.74874 & $* *$ & -3.71380 & $* *$ \\
\hline 1st Difference & & & & & & \\
\hline Maize & -2.96517 & $*$ & -4.80428 & $* * * *$ & & \\
\hline Rice & -3.76056 & $* * *$ & -3.44363 & $* *$ & & \\
\hline Wheat & -4.40132 & $* * * *$ & -4.80224 & $* * *$ & & \\
\hline
\end{tabular}

Notes: Results are generated with Eviews 6. Asterisks denote levels of significance (* for $10 \%$, ** for $5 \%$, *** for $2.5 \%$ and $* * * *$ for $1 \%)$. The critical values are $-2.89(10 \%),-3.19(5 \%),-3.46(2.5 \%)$ and $-3.77(1 \%)$.

Source: Authors' estimations.

Next, we conduct estimation based on the error-correction model corresponding to equation (3). Table 2 presents the estimates. We also present the 1- year (12-month) adjustments in the last column of Table 2. Shortrun effects are in fact the instant adjustment in month 0 , that is $n=0$ in equation (4). The adjustments will follow the direction as shown by the adjustment coefficient (AC). The positive AC suggests upward adjustment, and the negative AC suggests downward adjustment.

Table 2. Restricted Error-Correction Model Results

\begin{tabular}{|l|c|c|c|c|c|c|}
\hline & Constant $(\alpha)$ & $\begin{array}{c}\text { Adjustment } \\
\text { Coefficient }(\gamma)\end{array}$ & $\begin{array}{c}\text { Short-run } \\
\text { Effects }(\beta)\end{array}$ & $\begin{array}{c}\text { Adjusted } \\
R^{2}\end{array}$ & $\begin{array}{c}\text { DW } \\
\text { Statistics }\end{array}$ & $\begin{array}{c}12 \text {-month } \\
\text { Adjustment }\end{array}$ \\
\hline Maize & $2.1987^{* * * *}$ & $0.0136^{*}$ & $0.0653^{* *}$ & 0.0026 & 1.0735 & $20.6 \%$ \\
& $(1.6001)$ & $(0.3896)$ & $(1.1650)$ & & & $4.5 \%$ \\
\hline Rice & $1.8665^{* * * *}$ & $0.0043^{* * *}$ & $-0.0052^{* * *}$ & -0.3340 & 1.2351 & $10.2 \%$ \\
& $(2.0342)$ & $(0.9013)$ & $(-0.4435)$ & & 1.3682 & \\
\hline Wheat & $1.6054^{* * * *}$ & $0.0111^{* * * *}$ & $-0.0271^{* * * *}$ & 0.0229 & & \\
& $(2.3660)$ & $(1.3223)$ & $(-1.3364)$ & & & \\
\hline
\end{tabular}

Notes: These are estimates of equation (3), generated with Eviews 6. Asterisks denote levels of significance $(*$ for $10 \%$, ** for $5 \%$, $* * *$ for $2.5 \%$ and $* * * *$ for $1 \%$ ).

Source: Authors' estimations.

The world prices of these three commodities are transmitted weakly to China's market. The three commodities show a similar price transmission pattern. Their speeds of adjustment are less than $5 \%$.

\section{Policy Analysis}

It is necessary to look into the Chinese agricultural policy to better understand the transmission of international prices into China market is so week. China's domestic agricultural policies have undergone significant changes in the since 1990s. In this section, we investigate selected policy changes contributing to food commodity prices stability in China. China now allows most agricultural prices to be set by market forces, but the government intervenes in various ways to stabilize markets. Table 3 summarizes the main agricultural market stabilization policies the Chinese government used. We select a few to discuss in detail below.

Table 3. Summary of China's market stabilization measures

\begin{tabular}{|l|l|}
\hline \multicolumn{1}{|c|}{ Measure } & \multicolumn{1}{c|}{ Description } \\
\hline Reserve management & $\begin{array}{l}\text { Central and local authorities maintain large reserves of grains, vegetable oils, cotton, and pork to ensure } \\
\text { food security and intervene in markets. Authorities try to stabilize markets via auctions or additional } \\
\text { procurement. }\end{array}$ \\
\hline $\begin{array}{l}\text { Value added tax (VAT) } \\
\text { refunds or waivers }\end{array}$ & $\begin{array}{l}\text { At times, refunds of VAT payments are given for exports of specified commodities. Authorities also } \\
\text { can grant a waiver of VAT on imports of commodities in short supply. }\end{array}$ \\
\hline $\begin{array}{l}\text { Transportation tax } \\
\text { waivers }\end{array}$ & $\begin{array}{l}\text { Taxes on rail shipments may be waived to reduce the cost of grain shipments. Authorities also can } \\
\text { order railways to set aside cars for grain transport. }\end{array}$ \\
\hline Protection prices & Support prices may be established for selected grains in important production areas. \\
\hline $\begin{array}{l}\text { Administrative guid- } \\
\text { ance }\end{array}$ & $\begin{array}{l}\text { Farmers are generally free to make their own planting decisions, but local government authorities } \\
\text { sometimes issue directives or plans to increase production of certain crops. }\end{array}$ \\
\hline $\begin{array}{l}\text { Governors' responsibil- } \\
\text { ity system }\end{array}$ & $\begin{array}{l}\text { Provincial governors are charged with ensuring that grain supply and demand is balanced within their } \\
\text { province. }\end{array}$ \\
\hline
\end{tabular}

Source: US Department of Agriculture, http://www.ers.usda.gov/Briefing/China/stabilizationpolicy.htm, accessed on 10 June, 2009. 
Before examining the policy changes, it is useful to have overall look at China's trade and production of these commodities. This helps understand the different transmission patterns in the three commodities. Table 4 shows China's production and trade situation for the three food commodities from 2000 to 2006. The maize production increased from 106 million tons in 2000 to 145.5 million tons in 2006. The total maize import during this period was only 123 thousand tons. Comparing the year 2006 with 2000, for wheat, though the production didn't increase much, its import reduced in 2006 by about 30 thousand tons while export increased a lot. With production virtually unchanged, China reduced rice export and increased rice import.

Table 4. Trade and Production of Selected Food Commodities of China, 2000 - 2006

\begin{tabular}{|c|c|c|c|c|c|c|c|c|}
\hline \multicolumn{2}{|c|}{ Unit: 10 thousand tons } & 2000 & 2001 & 2002 & 2003 & 2004 & 2005 & 2006 \\
\hline \multirow[t]{3}{*}{ Maize } & Production & 10.600 & 11.409 & 12.131 & 11.583 & 13.029 & 13.937 & 14.548 \\
\hline & Import & 0.3 & 3.9 & 0.8 & 0.1 & 0.2 & 0.4 & 6.5 \\
\hline & Export & 1047.9 & 600.0 & 1167.5 & 1639.1 & 232.4 & 864.2 & 309.9 \\
\hline \multirow[t]{3}{*}{ Rice } & Production & 18.791 & 17.758 & 17.454 & 16.066 & 17.909 & 18.059 & 18.257 \\
\hline & Import & 24.9 & 29.3 & 23.8 & 25.9 & 76.6 & 52.2 & 73.0 \\
\hline & Export & 296.2 & 187.0 & 199.0 & 261.7 & 90.9 & 68.6 & 125.3 \\
\hline \multirow[t]{3}{*}{ Wheat } & Production & 9.964 & 9.387 & 9.029 & 8.649 & 9.195 & 9.745 & 10.447 \\
\hline & Import & 91.9 & 73.9 & 63.2 & 44.7 & 725.8 & 353.8 & 61.3 \\
\hline & Export & 18.8 & 71.3 & 97.7 & 251.4 & 108.9 & 60.5 & 151.0 \\
\hline
\end{tabular}

Source: Chinese Agriculture Development Report 2007 by Ministry of Agriculture of China, available at http://www.agri.gov.cn/sjzl/baipsh/WB2007.htm. Accessed on $30^{\text {th }}$ March 2009.

As an important factor to market salability, China's production of rice, maize and wheat keeps an increasing trend during the last 30 years. The rice production was 137 million tonnes in 1978, and it increased to 189 million tonnes in 2007. For maize and wheat, the production shows a much larger increase. The production of wheat doubled from 54 million tonnes in 1978 to 110 million tonnes in 2007. The maize production almost tripled from 56 million tonnes in 1978 to 152 million tonnes in 2007.

\subsection{Domestic Agricultural Policies}

The main objectives of Chinese agricultural policy have been centered around the issues, such as, food security, raising farm household income, food safety, environmental protection, agricultural competitiveness. The objectives enjoy different priorities during different periods. During the period from 1990 to 1997, the priority of the agricultural policies, especially the food policies, is to increase food commodity production, to secure food security. Since 1998, the major objective shifted to reduce farmer burdens and increase farmer household income. Competitiveness became an important objective as China accessed to the WTO in 2001. Currently, improving farmers' incomes and narrowing the urban-rural income gap are top priorities for the Chinese government, while food security and market stable remains a principal policy focus.

Price policy. Before 2004, China's rice, wheat and maize were subject to state pricing and state procurement system. In 2004, China liberalized the grain market, allowing qualified non-state firms to buy and sell grains on the opened market and permitting qualified private firms to take grain processing and storing activities (OECD, 2005). The state regulates the grain market through national grain stocks, state trading enterprises and minimum purchase prices.

From 2004, China exercises minimum purchase prices on selected grains, first rice, and then extends to wheat (OECD, 2007). Table 5 summarizes the sate-set minimum prices for rice and wheat from 2004 to 2008. In 2004 , the only rice was included in the system, and for early indica rice and japonica rice, the minimum prices were set at CNY 1,400 (USD 169) and CNY 1,500 (USD 181) per tonne respectively. China maintained the same level of prices during 2005 to 2007 in terms of the Chinese currency for rice, but extended to cover middle and late indica rice (from 2005) and wheat (from 2006). In fact, these prices did not take effect as market prices were higher than the minimum prices in 2004. In 2005, China bought early indica rice at the set minimum price. In 2008-10, the minimum prices for rice and wheat were increased each year independent of changes on international markets. Thus, rice prices remained much below those on international markets while those for wheat were artificially boosted pushing them above international levels in 2009 and 2010. 
Table 5. Minimum Purchase Prices for Rice and Wheat in China, 2004-2008

\begin{tabular}{|c|c|c|c|c|c|c|c|c|c|c|c|c|c|c|}
\hline & \multicolumn{2}{|l|}{2004} & \multicolumn{2}{|l|}{2005} & \multicolumn{2}{|l|}{2006} & \multicolumn{2}{|l|}{2007} & \multicolumn{2}{|l|}{2008} & \multicolumn{2}{|l|}{2009} & \multicolumn{2}{|l|}{2010} \\
\hline & CNY & USD & CNY & USD & CNY & $\mathrm{CNY}$ & USD & $\mathrm{CNY}$ & USD & USD & CNY & USD & CNY & USD \\
\hline Rice & & & & & & & & & & & & & & \\
\hline $\begin{array}{l}\text { Early indica } \\
\text { paddy rice }\end{array}$ & 1400 & 169 & 1400 & 171 & 1400 & 1800 & 264 & 1860 & 275 & 176 & 1400 & 186 & 1540 & 223 \\
\hline $\begin{array}{l}\text { Middle and } \\
\text { late } \\
\text { indica paddy } \\
\text { rice }\end{array}$ & & & 1440 & 176 & 1440 & 1840 & 269 & 1940 & 278 & 181 & 1440 & 191 & 1580 & 229 \\
\hline $\begin{array}{l}\text { Japonica } \\
\text { paddy rice }\end{array}$ & 1500 & 181 & 1500 & 183 & 1500 & 1900 & 278 & 2100 & 310 & 188 & 1500 & 199 & 1640 & 238 \\
\hline Wheat & & & & & & & & & & & & & & \\
\hline White wheat & & & & & 1440 & 1740 & 255 & 1800 & 266 & 181 & 1440 & 191 & 1540 & 223 \\
\hline $\begin{array}{l}\text { Red and } \\
\text { mixed wheat }\end{array}$ & & & & & 1380 & 1660 & 243 & 1720 & 254 & 173 & 1380 & 183 & 1440 & 209 \\
\hline
\end{tabular}

Source: OECD, 2009; OECD, 2011.

In 2006, wheat market prices fell below the minimum price levels, China's government purchased wheat at minimum prices, amounting to 41 million. This amount was accounted for over $80 \%$ of farmers' total sales and about $40 \%$ of total wheat production in 2006 . Government purchased nearly 4 million tonnes early indica rice, which was much smaller comparing with total rice production of about 181 million tonnes in 2006 (OECD, 2007). In 2007, the level and the coverage of intervention prices remained unchanged, but in 2008, the minimum prices were increased by $4 \%-7 \%$ for wheat and by $9 \%-10 \%$ for rice (OECD, 2009).

To keep a stable market, China started auction sales of the purchased grains since 2006. By the end of July 2006, China had sold out 6.72 million tonnes of rice purchased at the minimum price during the previous year. ${ }^{1}$ In 2007, the government held regular auctions at provincial wholesale markets releasing about 40 million tonnes of wheat from its stocks. As of the end of June 2009, there are 130 auction sales for rice, and 129 auction sales for wheat.

Direct Payments. Real rural incomes rose more than three-fold between 1980 and 2000. In addition, as Figure 2 shows, the grain production began to decline since 1998. As a result, the grain price rose sharply in late 2003. As one of the responsive measures, China started agricultural direct subsidy trials in 2002 in selected provinces, such as Henan provinces, the major food production area. China announced to implement agricutlural direct subsidy policy national wide in 2004 to support grain production and to increase grain producers' incomes. Payments are based on current area sown to rice, wheat or maize, and are financed from the National Grain Risk Fund.

The official payment rate is CNY 10 per $m u$ (USD 22/ha), ${ }^{2}$ but the rate differs from province to province as funding can be supplemented from local sources. For example, in Beijing and Shanghai the payment can exceed $50 \mathrm{CNY} / \mathrm{mu}$ (USD 109/ha). Central government funding for direct payments shows an upward trend, from CNY 11.6 billion (USD 1.4 billion) in 2004 to 13.2 billion (USD 1.6 billion) in 2005, 14.2 billion (USD 1.8 billion) in 2006 and 15.1 billion (USD 2 billion) in 2007 and 2008 (OECD, 2009).

Taxation. In 2004, China announced to phase out the agricultural tax over five years. However, China abolished agricultural tax three years ahead of schedule. The tax reform helped reduce farmers' tax burden by 22 billion yuan (US\$2.7 billion) in 2005, and 23.4 billion yuan (US\$2.8 billion) during the period from 2001 to 2004. Only three of the 31 provincial level areas on the Chinese mainland collected agricultural tax in 2005, while 28 others had abolished the tax. ${ }^{3}$

Input subsidies. To encourage production, Chinese government also subsidizes the purchases of fertilizer, seeds and agricultural machinery since early this century. The policy first covered improved quality soybean seeds in 2002 and then extended to the improved seeds of wheat, maize and rice. The amounts of budgetary for this purpose increased year by year. In 2002, it was CNY 100 million (USD 12 million), and then it

\footnotetext{
${ }^{1}$ See the news from Chins State Administration of Grains (CSAG) website, "The $17^{\text {th }}$ Auction Sales of Rice Purchased at Minimum Prices Makes Deal of 0.56 million Tonnes", http://www.chinagrain.gov.cn/n16/n1062/n1277099/1326044.html, accessed on 10 Jun, 2009

${ }^{2} \mathrm{Mu}$ is the Chinese measure for land area. A hectare is equivalent to $15 \mathrm{mu}$.

${ }^{3}$ See China Abolishes Agricultural Tax Three Years ahead of Schedule, http://www.china.org.cn/english/features/poverty/156685.htm. Accessed on 15 the May, 2009.
} 
amounted to CNY 2.85 billion (USD 0.3 billion) in 2004 and CNY 3.87 billion (US\$ 0.5 billion) in 2005 (OECD, 2007). The transferred amount was increased to CNY 4.07 billion (USD 0.51 billion) in 2006, then to CNY 6.66 billion (USD 0.88 billion) in 2007 and nearly doubled to CNY 12.1 billion (USD 1.75 billion) in 2008 (OECD, 2009).

However, the subsidy rate for wheat, soybean, maize, early indica rice keeps unchanged. This means that the planting acreage for these grains have increased over these year. For example, for wheat, the area covered doubled from 100 million $m u$ (6.7 million hectares) in 2007 to 200 million $m u$ (13.3 million hectares) in 2008; and for maize, the area jumped from 30 million $m u$ ( 2 million hectares) to 200 million mu (13.3 million hectares) over the same period (OECD, 2009).

The Chinese government provides a small subsidy for the purchase of farm machinery. China set budgetary allocation to subsidize specialized household to purchase of farm machinery in large grain-producing counties in 2004. Subsidies can cover up to 30 percent of the purchase price. This policy later covers all farmers. Farmers pay the subsidized price. Then the dealers collect the subsidy from the government agencies. The subsidy fund increased from CNY 480 million (USD 58 million) in 2004 to CNY 3.3 billion (USD 439 million) in 2007, and then increased to CNY 4 billion (USD 580 million) in 2008 (OECD, 2009). In some cases, subsidies for the purchases of fertilizer and improved seeds are paid to supply companies, with expectation of lowering the prices.

China launched comprehensive subsidy on agricultural inputs in 2006 to compensate farmers for an increase in prices of agricultural inputs such as fertilisers, pesticides, plastic films and diesel. In 2006 China allocated CNY 12 billion (USD 1.5 billion) on this programme, the amount more than doubled in 2007 to CNY 27.6 billion (USD 3.7 billion), which increased to CNY 63.8 billion (USD 9.2 billion) in 2008 (OECD, 2009).

\subsection{Agriculture Trade Policies}

\section{Import policy}

China has progressively reduced import tariffs on agricultural products as an effort to access to the WTO and in line with its WTO commitments. Applied tariff rates are very close to the bound rates. Applied tariffs on agricultural products fell from $23.1 \%$ in 2001 and $18.2 \%$ in 2002 to $15.3 \%$ in 2005 , which are still higher than overall average rate of $9.7 \%$ in 2005 and remains unchanged since then (WTO, 2006; WTO, 2008). In particular, tariffs on grains were reduced from $51.9 \%$ to 33.9 , which is still higher than average border protection. Since 2000, tariffs, even if falling, seem to be having more influence upon domestic prices as a result of a decline in domestic regulation (OECD, 2005). In addition, imports of agricultural goods are subject to VAT. The rate for agricultural products is $13 \%$.

China exercises tariff rate quotas (TRQs) on major agricultural products, such as wheat, maize, rice, etc. The National Development and Reform Commission (NDRC) and Ministry of Commerce (MOFCOM) are jointly responsible for administering TRQs for rice, maize and wheat. The size of the annual quota is based on China's commitments at the time of accession to the WTO (Table 6). Imports of rice, maize and wheat under TRQs remain low and quotas are generally unfilled. In 2007, grains, including rice, wheat and maize are still subject to TRQs.

While a greater array of firms are permitted to engage in foreign trade, the state-trading enterprises (STEs) remain deeply involved as importers with a role to play in implementing government policy, especially policies designed to stabilise domestic prices (OECD, 2005). The government still retains some influence on imports of key commodities through the state-trading system. Under China's Protocol of Accession, rice, wheat and maize are included in the commodities subject to import by STEs. STEs continue to control the majority of wheat $(90 \%)$, maize $(60-68 \%)$ and rice $(50 \%)$ imports.

Table 6. Tariff quota utilization in China, 2002-06

\begin{tabular}{|l|l|c|c|c|c|c|}
\hline & & $\mathbf{2 0 0 2}$ & $\mathbf{2 0 0 3}$ & $\mathbf{2 0 0 4}$ & $\mathbf{2 0 0 5}$ & $\mathbf{2 0 0 6}$ \\
\hline Wheat & Quota level ('000 tonnes) & $8,468.0$ & $9,052.0$ & $9,636.0$ & $9,636.0$ & $9,636.0$ \\
\hline & Out-of-quota imports ('000 tonnes) &.. &.. &.. &.. &.. \\
\hline & In-quota imports ('000 tonnes) & 632 & 450 & $7,260.0$ & 354.0 & 610 \\
\hline
\end{tabular}


Table 6 (cont.). Tariff quota utilization in China, 2002-06

\begin{tabular}{|l|l|c|c|c|c|c|}
\hline & & $\mathbf{2 0 0 2}$ & $\mathbf{2 0 0 3}$ & $\mathbf{2 0 0 4}$ & $\mathbf{2 0 0 5}$ & $\mathbf{2 0 0 6}$ \\
\hline & Utilization rate (\%) & 7.5 & 5.0 & 75.3 & 36.7 & 6.3 \\
\hline & State-trading share & 90.0 & 90.0 & 90.0 & 90.0 & 90.0 \\
\hline & In-quota MFN tariff rate (\%) & $1-10$ & $1-10$ & $1-10$ & $1-10$ & $1-10$ \\
\hline & Out-of-quota MFN tariff rate (\%) & 71.0 & 68 & 65 & 65 & 65 \\
\hline Maize & Quota level ('000 tonnes) & $5,850.0$ & $6,525.0$ & $7,200.0$ & $7,200.0$ & $7,200.0$ \\
\hline & Out-of-quota imports ('000 tonnes) &.. &.. &.. &.. &.. \\
\hline & In-quota imports ('000 tonnes) & 10 & $<5$ & $<5$ & 75 & 7.0 \\
\hline & Utilization rate (\%) & 0.2 & 0.1 & 0.1 & 0.1 & 1.0 \\
\hline & State-trading share & 68.0 & 64.0 & 60.0 & 60.0 & 60.0 \\
\hline & In-quota MFN tariff rate (\%) & $1-10$ & $1-10$ & $1-10$ & $1-10$ & $1-10$ \\
\hline & Out-of-quota MFN tariff rate (\%) & $28-71$ & $24-68$ & $20-65$ & $20-65$ & $20-65$ \\
\hline Rice & Quota level ('000 tonnes) & $3,990.0$ & $4,655.0$ & $5,320.0$ & $5,320.0$ & 5,320 \\
\hline & Out-of-quota imports ('000 tonnes) &.. &.. &.. &.. &.. \\
\hline & In-quota imports ('000 tonnes) & 237 & 260 & 770 & 520 & 729 \\
\hline & Utilization rate (\%) & 5.9 & 5.6 & 14.5 & 9.7 & 13.7 \\
\hline & State-trading share & 50.0 & 50.0 & 50.0 & 50.0 & 50.0 \\
\hline & In-quota MFN tariff rate (\%) & $1-9$ & $1-9$ & $1-9$ & $1-9$ & $1-9$ \\
\hline & Out-of-quota MFN tariff rate (\%) & $22-71$ & $16-68$ & $10-65$ & $10-65$ & $10-65$ \\
\hline
\end{tabular}

Note: Utilization rate refers to in-quota imports divided by quota level.

Source: WTO, 2006; WTO, 2008

Export measures. Under China's WTO accession agreements, China maintains the right to apply export taxes in order to maintain a balance between demand and supply in the domestic market. In general, China doesn't levy such taxes on agricultural products with very few exceptions. However, to curb domestic food price inflation and to guarantee domestic grain supplies during the food price spike, China levied provisional export taxes on grains and their flour products in 2008. Commodities included are rice, maize, wheat and soybean. China imposes global (i.e. irrespective of destination) quotas on grains (maize, rice, and wheat). In addition, rice and maize are subject to state trading.

\section{Conclusion}

The international prices for rice, maize and wheat increased dramatically during the period from 2006 to 2008 . The prices spike has been transmitted to many developing countries, causing unrest in those countries. However, the prices for those commodities in China keeps relative stable compared with the international prices. To test if the prices spike has been transmitted to China, we conduct an econometric analysis on the transmission of the international prices to China for the three food commodities: maize, rice and wheat. We focus on the recent food prices spike period. The estimations based on the error-correction model (ECM) suggest there are weak price transmissions for these three commodities.

Increasing domestic production and proper agricultural policies and trade policies explain the commodity price stability in China. While China now allows most agricultural prices to be set by market forces, the government exercises various measures to stabilize markets. We discuss the related policies in detail, such as price policy, agricultural subsidy policy, agricultural tax policy and trade policy. The policy reform has played an important role in stabilizing China food commodity market.

\section{References}

1. Baffes, J. and B. Gardner. (2003). The Transmission of World Commodity Prices to Domestic Markets under Policy Reforms in Developing Countries, Journal of Policy Reform, 6(3), 159-180.

2. Baffes, John and Mohamed I. Ajwad. (1998). Detecting Price Linkages: Methodological Issues and an Application to the World Market of Cotton, World Bank Working Paper, 1944.

3. Conforti, Piero. (2004). Price transmission in selected agricultural markets, FAO Commodity and Trade Policy Research Working Paper, No. 7, March 2004.

4. Dawe, David. (2008). Have recent increases in international cereal prices been transmitted to domestic economies? The experience in seven large Asian countries, FAO ESA Working Paper No. 08-03 www.fao.org/es/esa, accessed on April 15, 2009.

5. Engle, R. F. and Granger, C. W. (1987). Co-integration and error correction: representation, estimation, and testing, Econometrica, 55:252-276. 
6. Gale, Fred, Bryan Lohmar and Francis Tuan. (2005). China's New Farm Subsidies, Economic Research Service/USDA, Washington, DC, February, 2005. Available at: www.ers.usda.gov/publications/WRS0501/ WRS0501.pdf, accessed on 10 June, 2009.

7. Hendry, D. F. et al. (1984). Dynamic Specification in Griliches, Z. and Intriligator, M. D. (eds.) Handbook of Econometrics, Vol.2, Amsterdam: North Holland Publishing Co.

8. Imai, Katsushi, Raghav Gaiha and Ganesh Thapa. (2008). Transmission of World Commodity Prices to Domestic Commodity Prices in India and China, Brooks World Poverty Institute (BWPI) Working Paper No.45, June 2008.

9. Mundlak, Yair and Donald F. Larson. (1992). On the Transmission of World Agricultural Prices, The World Bank Economic Review, 6 (33), 9-422.

10. National Bureau of Statistics of China. (2008). China Statistical Yearbook 2008, Beijing, China: China Statistic Press.

11. OECD. (2005). OECD Review of Agricultural Policies: China, Paris.

12. OECD. (2007). Agricultural Policies in Non-OECD Countries: Monitoring and Evaluation, Paris.

13. OECD. (2009). Agricultural Policies in Emerging Economies: Monitoring and Evaluation, Paris.

14. OECD. (2011). Agricultural Policy Monitoring and Evaluation 2011: OECD Countries and Emerging Economies, Paris.

15. Sharma, Ramesh. (2003). The Transmission of World Price Signals: the Concept, Issues, and Some Evidence from Asian Cereal Markets, in OECD (eds) Agricultural Trade and Poverty: Making Policy Analysis Account, OECD: Paris.

16. Sharma, Ramesh and Panos Konandreas. (2008). WTO Provisions in the Context of Responding to Soaring Food Prices, FAO Commodity and Trade Policy Research Working Paper, 25, October, Rome, Italy.

17. WTO. (2006). China Trade Policy Review (Report by the Secretariat), WT/TPR/S/161, April. Available at: http://www.wto.org/english/tratop_e/tpr_e/tp262_e.htm, accessed on 10 June, 2009.

18. WTO. (2008). China Trade Policy Review (Report by the Secretariat), WT/TPR/S/199, May. Available at: http://www.wto.org/english/tratop_e/tpr_e/tp299_e.htm, accessed on 10 June, 2009. 